\title{
Pollination service of Nannotrigona testaceicornis stingless bees in strawberry
}

\section{Serviço de polinização da abelha Nannotrigona testaceicornis no morangueiro}

\author{
Giuliana Ribeiro da Silva1* (10) (https://orcid.org/0000-0001-5703-5085) \\ Raquel Pérez-Maluf ${ }^{1}$ (i) (https://orcid.org/0000-0001-5385-0760) \\ Generosa Sousa Ribeiro' (1) (https://orcid.org/0000-0003-0320-9179) \\ Ana Luiza de Jesus Gusmão' (1) (https://orcid.org/0000-0001-8122-410X)
}

\begin{abstract}
Strawberry presents moderate dependence on bee pollination service, and pollination is related to the production and quality of fruits. The aim of this study was to evaluate the pollination service provided by Nannotrigona testaceicornis stingless bees in strawberry. Primary flowers of cultivar San Andreas were used in a completely randomized experimental design, with twelve replicates and five types of pollination: one $N$. testaceicornis visit (1V); two $N$. testaceicornis visits $(2 \mathrm{~V})$; three $N$. testaceicornis visits $(3 \mathrm{~V})$; natural pollination (NP); self-pollination (SP). In flowers visited by $N$. testaceicornis, movements and visit time were observed. The following fruit characteristics were evaluated: fruit biometry, fecundation rate of achenes, postharvest fruit quality, contribution of pollination agents and mechanisms on average fruit weight. In fruit biometry, pollination service contributed only in longitudinal length, which was higher in NP and $3 \mathrm{~V}$, compared to SP. In the different types of pollination, the fertilization rate of achenes did not differ and showed no effect on fresh fruit weight. In post-harvest fruit quality, $1 \mathrm{~V}, 3 \mathrm{~V}$ and NP showed better results regarding degree of deformation and marketability. Nannotrigona testaceicornis stingless bees and natural pollination contributed to the average fresh weight of strawberry fruits. Nannotrigona testaceicornis stingless bees and natural pollination provided improvement in quality and added value of fruits. Nannotrigona testaceicornis stingless bees were effective strawberry pollinators.
\end{abstract}

KEYWORDS: stingless bees; Fragaria $\times$ ananassa; quality fruits.
RESUMO: O morangueiro apresenta dependência moderada quanto ao serviço de polinizaçáo por abelhas, e sua polinização está relacionada com a produçáo e a qualidade das frutas. Diante disso, o objetivo deste estudo foi avaliar o serviço de polinização da abelha Nannotrigona testaceicornis no morangueiro. Utilizaram-se flores primárias do cultivar San Andreas no delineamento experimental inteiramente casualizado, com doze repetiçóes e cinco tipos de polinização: uma visita de $N$. testaceicornis (1V); duas visitas de $N$. testaceicornis $(2 \mathrm{~V})$; três visitas de $N$. testaceicornis $(3 \mathrm{~V})$; polinização natural $(\mathrm{PN})$ e autopolinização $(\mathrm{AP})$. Os movimentos e o tempo de visita nas flores foram observados nas visitas de $N$. testaceicornis. Nas frutas, avaliaram-se as características: biometria das frutas, taxa de fecundação dos aquênios, qualidade pós-colheita, contribuição de agentes e mecanismos de polinização na massa média das frutas. Na biometria das frutas, o serviço de polinização contribuiu no comprimento longitudinal, que se apresentou mais elevado na $\mathrm{PN}$ e $3 \mathrm{~V}$, em relação à $\mathrm{AP}$. Nos diferentes tipos de polinização, a taxa de fecundaçáo dos aquênios não diferiu e não apresentou efeito sobre a massa fresca das frutas. Na qualidade pós-colheita, $1 \mathrm{~V}, 3 \mathrm{~V}$ e $\mathrm{PN}$ apresentaram melhores resultados no grau de deformação e frutas comercializáveis. A abelha $N$. testaceicornis e a polinização natural contribuíram na massa fresca média das frutas de morangueiro. Os serviços de polinização natural e de $N$. testaceicornis proporcionaram melhoria na qualidade e agregação de valor das frutas. A abelha $N$. testaceicornis apresentou-se como polinizadora efetiva do morangueiro.

PALAVRAS-CHAVE: abelha sem ferrão; Fragaria $\times$ ananassa; qualidade de frutas. 


\section{INTRODUCTION}

The pollination service is understood as an ecosystem service of utmost importance for food production (SANDHU et al., 2016). When evaluating different agricultural crops and their dependence on pollination services, GIANNINI et al. (2015) and GHOSH; JUNG (2016) classified strawberry with moderate degree of dependence and found improvement in fruit quality as a benefit of pollination.

Strawberry flowers are hermaphroditic; however, the dependence on entomophilous pollination is due to the high number of stigmas, which vary according to the position of flowers in the inflorescence, with approximately 350 stigmas in primary flowers, 260 in secondary flowers, and 180 in tertiary flowers (TUOHIMETSÄ et al., 2014). In addition, the processes of fertilization of stigmas and development of achenes originating from pollination are responsible for promoting the synthesis of hormones, which induce fruit growth by increasing the number and size of cells in the strawberry flower receptacle (ARIZA et al., 2011; CSUKASI et al., 2011).

In strawberry, the designation of fruit is used when referring to the flower receptacle and its shape is the result of pollen distribution in stigmas (KLATT et al., 2014). The absence of uniform pollen distribution on stigmas in regions of flower receptacle due to deficient pollination results in unfertilized stigmas and, consequently, deformed fruits (MALAGODI-BRAGA; KLEINERT, 2007).

Pollination deficit in strawberry, especially in the absence of pollinating insects, can be quite significant and is expressed in several fruit characteristics such as fresh weight, equatorial diameter, longitudinal length, deformations, and, consequently, in value for the fresh market. KLATT et al. (2014) found lower fresh weight in self-pollination when compared with natural pollination by bees. In addition, bee pollination has improved the classification of fruits as marketable for the fresh market, compared to self-pollination. In pollination by Nannotrigona testaceicornis bees, ROSELINO et al. (2009) verified higher quality of strawberry fruits regarding the absence of deformations, equatorial diameter and fresh weight in comparison to self-pollination and natural pollination.

Stingless social bees from Meliponini and Trigonini tribes such as Tetragonisca angustula, Plebeia nigriceps, Scaptotrigona aff. depilis, Trigona spinipes and $N$. testaceicornis have been managed for pollination services in strawberry crops (ANTUNES et al., 2007; MALAGODI-BRAGA; KLEINERT, 2007; ROSELINO et al., 2009; WITTER et al., 2012). Among them, the species $N$. testaceicornis, known as iraí, distributed among the Brazilian states of Bahia, Espírito Santo, Goiás, Minas Gerais, São Paulo and Rio de Janeiro (SILVEIRA et al., 2002), is a promising species for pollination services. However, in strawberry cultivation in open field conditions, pollination by this bee species needs to be characterized. Therefore, the aim of this study was to evaluate the pollination service of $N$. testaceicornis stingless bees in strawberry.

\section{MATERIAL AND METHODS}

The study was conducted in a strawberry crop (14\% $47^{\prime} 21^{\prime \prime} S$; $40^{\circ} 43^{\prime} 43^{\prime \prime} \mathrm{W}$ and $937 \mathrm{~m}$ a.s.l.) cultivated in the semiorganic system, located in the municipality of Vitória da Conquista, Bahia, in the period from June 2016 to April 2017. According to the Köppen classification, the climate of the region is high-altitude tropical, with dry winter and mild summer. The soil of the experimental area was classified as eutrophic yellow latosol (SANTOS et al., 2006).

'San Andreas' strawberry crop was implemented in open field using Chilean bare root seedlings. Eighty seedlings were planted per flower bed with the following dimensions: $0.40 \mathrm{~m}$ in height, $1.0 \mathrm{~m}$ in width and $14 \mathrm{~m}$ in length, $0.4 \mathrm{~m}$ spacing between beds and $0.30 \times 0.30 \mathrm{~m}$ spacing between plants, with two rows per bed. Only one bed was used for this study, in the plant-to-plant drip irrigation system and fertigation, carried out according to the crop's water requirement. The bed was covered with double-sided polyethylene film with $30 \mu$ in thickness, with white face facing up.

Production system without the use of pesticides to control pests and diseases was adopted. The control of pests and diseases was carried out by means of natural alternative products, with tobacco and coconut soap extract. Cultural management such as the removal of diseased leaves and fruits with symptoms of diseases and attack by pests was also adopted. Fertilizations were carried out by means of organic fertilizers and synthetic mineral fertilizers, and the nutritional needs of plants were met according to soil analysis and fertilization recommendations for strawberry cultivation.

In October 2016, five boxes of populated $N$. testaceicornis colonies were implanted in the production field, which were arranged in front of strawberry beds, two meters away, three boxes distributed on one side of the bed and two boxes on the opposite side.

The experimental design used was completely randomized, with twelve replicates and the following pollination treatments: one $N$. testaceicornis visit (1V); two $N$. testaceicornis visits (2V); three $N$. testaceicornis visits (3V); natural pollination (NP); self-pollination (SP).

Flowers destined to treatments were randomly chosen in the production bed. Only primary flowers of inflorescences were chosen, one day before anthesis, and all, except for natural pollination, were bagged with voile fabric to control treatments. After floral anthesis, the voile tissue was removed from $1 \mathrm{~V}, 2 \mathrm{~V}$ and $3 \mathrm{~V}$ treatments, and $N$. testaceicornis visits in 
each flower, movements performed on stigmas and anthers and the visit time being observed. After completing the number of visits determined, flowers were again bagged until fruit development, growth and maturation. The 60 fruits from treatments were harvested when they presented $75 \%$ of their external surface in red to fully ripe color. Fruits were evaluated on the same day of harvest.

\section{The following characteristics were evaluated:}

(a) Fruit biometry: Longitudinal length $(\mathrm{mm})$ and equatorial diameter $(\mathrm{mm})$ of fruits were determined using a caliper. Longitudinal length was considered as the region between the base and the apex of the fruit and the equatorial diameter as the median region of the fruit. Fresh fruit weight was obtained by weighing fruits on a $0.1 \mathrm{mg}$ precision scale.

(b) Fertilization rate of achenes: Achenes were manually removed from fruits with the aid of tweezers and placed in containers with water; achenes that sank in water were considered fertilized and those that floated were considered as not fertilized, according to methodology of MALAGODI-BRAGA (2002). The fertilization rate of achenes was calculated according to the proportion between the number of fertilized achenes divided by the total number of achenes per fruit, expressed as percentage.

(c) Postharvest fruit quality: Fruits were classified according to class and category, according to norms of the Brazilian Program for the Modernization of Horticulture \& Integrated Strawberry Production (PBMH \& PIMo, 2009). Class was defined by measuring the largest equatorial fruit diameter $(\mathrm{mm})$. Fruits with equatorial diameter between 15 and $35 \mathrm{~mm}$ were considered belonging to class 15 , and those with equatorial diameter greater than $35 \mathrm{~mm}$ as belonging to class 35 . Regarding category, three groups were considered: no deformation, slight deformation (0-30\%), and strong deformation (>30\% deformation). Fruits were also classified as marketable and not marketable in relation to the fresh market.

(d) Contribution of pollination agents and mechanisms to the average fruit weight: The percentages of contribution to the average fruit weight of each pollination agent and mechanism were calculated, namely: $N$. testaceicornis pollination, self-pollination and natural pollination. Calculations were obtained using Eqs 1, 2 and 3, adapted from the formula proposed by ŻEBROWSKA (1998).

$$
\begin{gathered}
\mathrm{P}=\mathrm{Pi}-\mathrm{Pa} / \mathrm{Pi} \times 100 \\
\mathrm{~A}=\mathrm{Pa} / \mathrm{Pl} \times 100
\end{gathered}
$$

$$
\operatorname{Pn}=100-(P+A)
$$

where: $\mathrm{P}=$ contribution of $N$. testaceicornis; $\mathrm{A}=$ contribution of self-pollination promoted by gravity and wind; $\mathrm{Pn}=$ contribution of natural pollination promoted by gravity, wind, $N$. testaceicornis and other insects; $\mathrm{Pi}=$ average fruit weight obtained from $N$. testaceicornis pollination; $\mathrm{Pa}=$ average fruit weight obtained from self-pollination; $\mathrm{Pl}$ = average fruit weight obtained from natural pollination.

Data obtained were submitted to normality and homogeneity tests of variances, proceeding to analysis of variance at $1 \%$ probability, comparison of means by the Tukey's test $(\mathrm{p}<0.05)$ and Kruskal-Wallis test $(\mathrm{p}<0.05)$ for nonhomogeneous data. Distribution of relative frequencies in fruit classification was carried out, which were compared with the Pearson's chi-square test $\left(\mathrm{X}^{2}\right)$ at $5 \%$ probability to verify, more precisely, the effect of treatments on fruit classifications. In addition, data were also submitted to Pearson's correlation coefficient $(\mathrm{p}<0.05)$. Analyses were performed using the R CORE TEAM statistical software (2017).

\section{RESULTS AND DISCUSSION}

Significant difference was observed among $N$. testaceicornis pollination treatments for the average visit time in flowers. Flowers visited three times showed longer average visit time (Table 1). The characteristic longitudinal fruit length showed difference in the analysis of variance and the highest average value was verified for natural pollination in relation to flowers visited twice by $N$. testaceicornis and self-pollination, while fruits from flowers visited once by $N$. testaceicornis were similar to all other treatments (Table 1).

Regarding treatments that received one, two and three $N$. testaceicornis visits, no difference was observed for longitudinal fruit length, and only treatment with three visits was superior compared to self-pollination. In addition, no influence of visit time on longitudinal fruit length was observed among treatments with $N$. testaceicornis, even though in flowers visited three times, the average visit time was longer than in flowers visited one or two times (Table 1).

Thus, it could be inferred that the pollination service by bees was superior in flowers visited three times by $N$. testaceicornis and with natural pollination in relation to the other treatments, due to the number of visits, number of visiting species and visit time. Flowers visited three times by $N$. testaceicornis were visited by different individuals of the same species. In natural pollination, greater number of visits, visit time and different floral visitors are expected, since flowers were exposed throughout their floral longevity. In natural pollination during the experimental period, in addition to $N$. testaceicornis, the following species of floral visiting bees 
were verified: Tetragonisca angustula, Apis mellifera, Trigona spinipes and Paratrigona subnuda.

Therefore, flowers visited three times by $N$. testaceicornis and natural pollination favored cross-pollination among flowers. Therefore, cross-pollination contributed to the higher longitudinal fruit length for these treatments compared to self-pollination.

SHARMA et al. (2014) also found an increase in the longitudinal fruit length of five strawberry cultivars with $A$. mellifera pollination service, evidencing that cross-pollination, through managed pollinators in strawberry cultivation is related to longitudinal fruit length. However, the results obtained differ from those obtained by ROSELINO et al. (2009) in the cultivar Camarosa, which presented similar results for self-pollination, $N$. testaceicornis pollination and natural pollination treatments. These results indicate for the cultivar San Andreas, the importance of the pollination service by bees in the characteristic longitudinal fruit length.

Regarding the equatorial diameter of fruits, there was no difference among types of pollination (Table 1 ). This result is similar to that of WITTER et al. (2012), who obtained averages similar and close to those verified in this study for the equatorial diameter of fruits for the cultivars Aromas, Diamante and Cegnidarem in self-pollination, natural pollination and Plebeia nigriceps pollination. Unlike results obtained in this study, for the same characteristic, ROSELINO et al. (2009) found for 'Camarosa' higher mean equatorial diameter values of fruits obtained from $N$. testaceicornis pollination compared to other types of pollination.

The relationship between pollination service and equatorial diameter of strawberry fruits may be related to the behavior of bee movement in the lateral and basal regions of the flower receptacle, transport and deposition of pollen on stigmas of these regions and consequent fertilization (MALAGODI-BRAGA; KLEINERT, 2007). This statement is confirmed by the process of fertilization of stigmas and the development of achenes, responsible for promoting the synthesis of hormones such as auxin and gibberellin, which enable the increase in the number and size of flower receptacle cells (ARIZA et al., 2011; CSUKASI et al., 2011).

Comparing the results obtained for equatorial diameter with those of ROSELINO et al. (2009), who verified average of $76 \mathrm{~N}$. testaceicornis visits per flower in greenhouse, the cross-pollination and the behavior of bee movement in flowers possibly promoted an increase in the equatorial diameter of fruits due to the pollen distribution in the lateral and basal regions of the flower receptacle. However, in the present study, although circular movements were observed in these regions of the flower receptacle, the pollination service for this bee species did not differ for equatorial diameter, probably because the number of visits to flowers was limited to the maximum of three.

In the fertilization rates of achenes, entomophilic pollination promoted the same results as self-pollination (Table 1). Contrary to results verified in this study, KLATT et al. (2014) and ADHIKARI; MIYANAGA (2016) found a considerable increase in the fertilization rate of achenes from bee pollination compared to self-pollination.

Thus, in the present study, parameter fertilization rate of achenes did not seem to be sufficient to express the effect of the pollination service on strawberry fruits. It is assumed that, although fertilization rates were similar, the fertilization of achenes occurred in different regions of the flower receptacle, according to the type of pollination. It is possible to infer that, the fertilization of achenes in the self-pollination treatment was concentrated in the basal and lateral regions of the flower receptacle; whereas, in entomophilous pollination, fertilization occurred homogeneously in flowers.

The characteristic fresh fruit weight did not differ in the different pollination treatments (Fig. 1).

Table 1. Average visit time (AVT) of Nannotrigona testaceicornis - one visit (1V), two visits (2V) and three visits ( $3 \mathrm{~V}$ ). Mean, standard deviation and analysis of variance of longitudinal length (LL), equatorial diameter (ED) and fertilization rate of achenes (FRA) as a function of the number of $N$. testaceicornis visits, natural pollination (NP) and self-pollination (SP).

\begin{tabular}{lcccc} 
Pollination & 'AVT $(\mathrm{sec})$ & LL $(\mathrm{mm})$ & ED $(\mathrm{mm})$ & FRA (\%) \\
\hline IV & $212.2 \mathrm{~b}$ & $36.2 \pm 8.0 \mathrm{abc}$ & $26.49 \pm 7.2 \mathrm{a}$ & $62.79 \pm 16.3 \mathrm{a}$ \\
\hline $2 \mathrm{~V}$ & $195.7 \mathrm{~b}$ & $31.2 \pm 9.2 \mathrm{bc}$ & $24.63 \pm 7.4 \mathrm{a}$ & $58.53 \pm 14.0 \mathrm{a}$ \\
\hline $3 \mathrm{~V}$ & $839.0 \mathrm{a}$ & $37.7 \pm 7.1 \mathrm{ab}$ & $25.36 \pm 3.9 \mathrm{a}$ & $55.61 \pm 15.7 \mathrm{a}$ \\
\hline NP & & $41.1 \pm 5.7 \mathrm{a}$ & $29.67 \pm 4.6 \mathrm{a}$ & $51.17 \pm 15.1 \mathrm{a}$ \\
\hline SP & & $27.8 \pm 7.0 \mathrm{c}$ & $24.77 \pm 4.4 \mathrm{a}$ & $60.56 \pm 14.3 \mathrm{a}$ \\
\hline CV(\%) & & 21.58 & 21.78 & 26.12 \\
\hline F Test & & $334.05^{* *}$ & $52.00^{\mathrm{ns}}$ & $245.15^{\mathrm{ns}}$ \\
\hline
\end{tabular}

Means followed by the same letter in column do not differ by the Tukey's test at $5 \%$ probability; 'Means followed by the same letter in column do not differ by the Kruskal-Wallis test at $5 \%$ probability. ${ }^{*}$ Significant at $1 \%$ probability and ${ }^{\mathrm{n}}$ not significant by the $\mathrm{F}$-test. 
When comparing $N$. testaceicornis pollination with other types of pollination, ROSELINO et al. (2009) obtained higher fresh weight averages in 'Camarosa' with this bee species. KLATT et al. (2014) and ABROL et al. (2019) obtained higher fresh weight of fruits from bee pollination in relation to self-pollination, which is contrary to results obtained in this study. However, similar results have been verified by TUOHIMETSÄ et al. (2014), when studying twelve strawberry cultivars, nine of which had similar fresh fruit weight in self-pollination and cross-pollination treatments.

The results showed that the entomophilous pollination service was not sufficient to pollinate all flower stigmas in order not to provide differences in fresh weights between treatments with insect pollination and self-pollination (Fig. 1).

In this study, in all pollination treatments, the fertilization rate of achenes had no effect on the fresh fruit weight $(1 \mathrm{~V}$ : $\mathrm{r}=0.1837 ; 2 \mathrm{~V}: \mathrm{r}=0.0184 ; 3 \mathrm{~V}: \mathrm{r}=0.3718 ; \mathrm{NP}: \mathrm{r}=0.3817$; SP: $r=0.5436$ ), although the fresh weight of strawberry fruits and the fertilization rate of achenes are normally correlated (ZAPATA et al., 2014). This was probably because the entomophilous pollination service and self-pollination were not sufficient to fertilize all achenes, according to the average fertilization rate in previously presented pollination treatments (Table 1), consequently these two characteristics were not correlated.

In the relative frequencies of fruit classes, class 15 was predominant in all types of pollination, while class 35 was predominant only in natural pollination, one and two $N$. testaceicornis visits. However, the relative frequencies of classes showed no difference among treatments $\left(\mathrm{X}^{2}=4.36\right.$; $\mathrm{p}>0.05$ ) (Fig. 2).

This result can be explained by the bee movement in flowers in the basal and lateral regions of the flower receptacle,

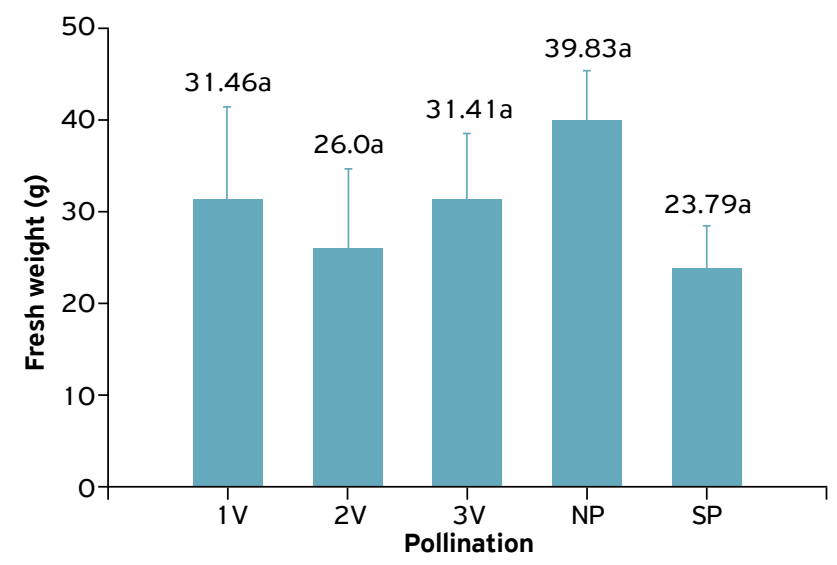

Figure 1. Fresh weight of strawberry fruits from Nannotrigona testaceicornis pollination - one visit ( $1 \mathrm{~V})$, two visits $(2 \mathrm{~V})$, three visits (3V), natural pollination (NP) and self-pollination (SP). Averages followed by the same letter do not differ by the KruskalWallis test at $5 \%$ probability. which provides the development of the equatorial region of fruits, as previously described. Under the conditions of this experiment, the pollination service through bee movements in regions of the flower receptacle did not provide improvement in fruit class with entomophilous pollinations.

The relative frequencies of fruit deformations showed differences among treatments $\left(\mathrm{X}^{2}=25.83 ; \mathrm{p}<0.05\right)$, confirming that the higher the pollination service, as previously described, the lesser or no deformations in fruits are observed (Fig. 3).

The degree of deformation in fruits is directly related to the pollen distribution in flower stigmas. According to KLATT et al. (2014), pollinating insects, when distributing pollen in flowers, fertilize stigmas, which homogeneous fertilization results in the homogeneous growth of the flower receptacle due to the action of hormones, resulting in well-formed fruits.

This was verified in this study, because fruits obtained with natural pollination presented higher frequency of absent deformations in relation to other treatments. Fruits from three $N$. testaceicornis visits and natural pollination did not present strong deformations, while fruits from one and two $N$. testaceicornis visits showed frequencies of strong deformations; however, treatment with one visit showed lower frequency of fruits with strong deformations compared to treatment with two visits (Fig. 3).

Regarding the average visit times in $1 \mathrm{~V}, 2 \mathrm{~V}$ and $3 \mathrm{~V}$ (Table 1), it was also verified that $3 \mathrm{~V}$, with the longest visit time, provided fruits without strong deformations (Fig. 3). These results confirm that the bee pollination service provided improved fruit quality regarding fruit formation, decreasing the degree of deformation of strawberry fruits destined for the fresh market.

Similar results were verified by ADHIKARI; MIYANAGA (2016) with Anthophora plumipes bee in strawberry, which obtained high proportion of fruits without deformation or with slight deformation, with 78 and $20 \%$, respectively, which shows the importance of the pollination service for fruit quality regarding the absence of deformations.

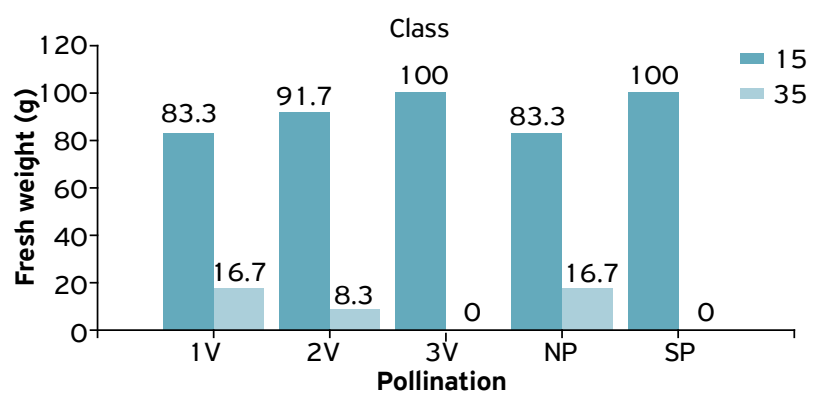

Figure 2. Relative frequency of classes of strawberry fruits from Nannotrigona testaceicornis pollination - one visit (1V), two visits (2V), three visits ( $3 \mathrm{~V})$, natural pollination (NP) and self-pollination (SP). 
The presence of fruits with slight deformations was frequent in all treatments, but mainly in fruits obtained with $N$. testaceicornis pollination. This result elucidates that only one bee species, although sufficient to reduce the degree of deformation in fruits, may not be sufficient to distribute pollen in all flower stigmas. However, this result can also be explained by the number of visits limited to maximum of three $N$. testaceicornis visits to flowers, which is not enough to distribute pollen in all stigmas in the different regions of the flower receptacle.

The greater the number of bee species visiting strawberry flowers, the greater the complementary effect on pollination, as each bee species has a particular movement pattern in flowers (MALAGODI-BRAGA; KLEINERT, 2007; BLÜTHGEN; KLEIN, 2011). This effect was verified in natural pollination (Fig. 3), which, although presenting slight deformations, it is assumed that the pollination service was performed by several bees. Probably, only one bee species combined with the limited number of visits to flowers was not able to supply all the need for pollen distribution among stigmas of strawberry flowers and, therefore, caused fruits with slight deformations.

Self-pollination shows high frequency of fruits with strong deformations compared to bee pollination (Fig. 3). Similar results were obtained by ZAPATA et al. (2014), ADHIKARI; MIYANAGA (2016) in strawberry, confirming that self-pollination is not able to distribute pollen evenly among stigmas and, consequently, unfertilized areas originate deformed fruits. Thus, the results verified in this study confirm that, although strawberry flowers are self-fertile, they are not sufficient to provide adequate pollination for the production of well-formed fruits.
The frequencies of marketable and nonmarketable fruits for the fresh market showed differences according to the type of pollination $\left(X^{2}=25.83 ; p<0.05\right)$. Thus, the entomophilous pollination service had positive influence on the classification of fruits as marketable (Fig. 4).

Natural pollination and three $N$. testaceicornis visits showed higher frequencies of marketable fruits, followed by one and two $N$. testaceicornis visits. Therefore, in terms of time and number of visits, higher pollination services provided higher frequencies of marketable fruits, compared to self-pollination (Fig. 4).

The high frequency of marketable fruits in natural pollination occurred because, in addition to $N$. testaceicornis, other bee species visited strawberry flowers, resuming the complementary effect of pollination, which was also verified by MALAGODI-BRAGA; KLEINERT (2007) when using four visits with two bee species in the cultivar Oso Grande.

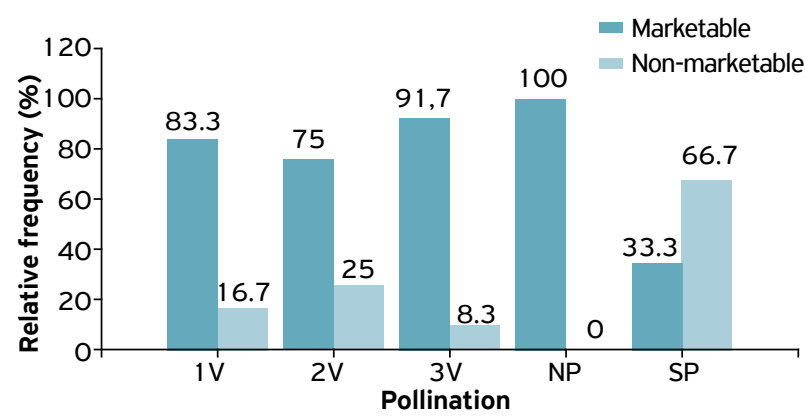

Figure 4. Relative frequency of marketable and nonmarketable strawberry fruits from Nannotrigona testaceicornis pollination one visit ( $1 \mathrm{~V})$, two visits ( $2 \mathrm{~V}$ ), three visits ( $3 \mathrm{~V})$, natural pollination (NP) and self-pollination (SP).

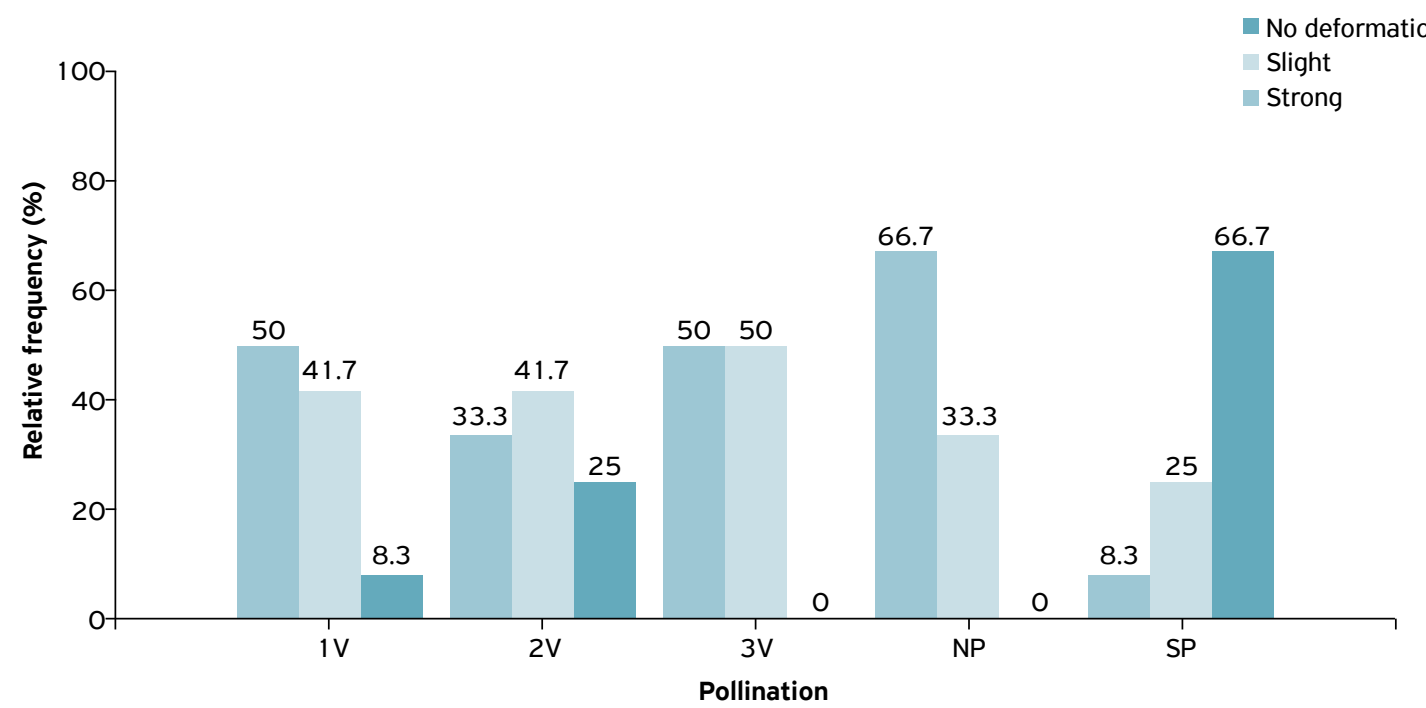

Figure 3. Relative frequency of the degree of deformation of strawberry fruits from Nannotrigona testaceicornis pollination - one visit ( $1 \mathrm{~V})$, two visits (2V), three visits (3V), natural pollination (NP) and self-pollination (SP). 
BARTOMEUS et al. (2014) also verified the impact of the pollination service on the classification of strawberry fruits, and entomophilous pollination, mainly by bees, provided better classification of fruits as marketable, compared to the absence of pollinating insects.

Therefore, pollinations with one and three $N$. testaceicornis visits presented well-formed or slightly deformed fruits, consequently, high frequency of marketable fruits to the fresh market, while, fruits from two $N$. testaceicornis visits presented different degrees of deformations; however, with high frequency of fruits with strong deformations, being unsuitable for the fresh market. In self-pollination, deformations were concentrated in the apical region of fruits and the high frequency of fruits with strong deformations made them unsuitable for the fresh market. Fruits from natural pollination were suitable for the fresh market, as they are well-formed, although in this treatment, fruits with slight deformations were observed.

The results obtained confirm that higher pollination services provided by $N$. testaceicornis and natural pollination, as previously described, allowed fruits to reach the marketable standard for the fresh market.

Similar results were obtained by ROSELINO et al. (2009) in strawberries in a protected environment, where $N$. testaceicornis pollination positively contributed to fruit formation, with $98 \%$ of well-formed fruits, adding commercial value to fruits under the effect of the pollination service.

In general, the results regarding to the degree of deformation of fruits and marketable fruits to the fresh market demonstrated the economic value of the pollination service provided by bees for strawberry cultivation. Thus, this study confirms the importance of the pollination service in strawberry, a crop of moderate dependence on pollination services (GIANNINI et al., 2015; GHOSH; JUNG, 2016).

Regarding the contribution of different pollination agents and mechanisms in the average fresh fruit weight (Table 2), it was found that the self-pollination mechanism contributed with $66.1 \%$ in the fresh fruit weight; however, pollination agents also contributed significantly.

Table 2. Contribution (\%) by different pollination agents and mechanisms in the average fresh weight of primary strawberry fruits using the formula adapted from ŻEBROWSKA (1998).

\begin{tabular}{lc|}
\hline Pollination agents & Contribution (\%) \\
\hline Self-pollination & 66.10 \\
\hline Nannotrigona testaceicornis* & 22.60 \\
\hline Natural pollination & 11.30 \\
\hline
\end{tabular}

*Values obtained for one, two and three visits.
The contribution percentage refers to the pollination value, expressed in fresh fruit weight, that is, the extent to which pollination agents and mechanisms pollinated flower stigmas. Self-pollination is a mechanism constituted by the action of gravity in the deposition of pollen under the stigmas, while pollinating agents are wind and visiting insects.

In this study, the results showed that self-pollination was able to pollinate $66.1 \%$ of flower stigmas due to the position of anthers in relation to stigmas of the flower receptacle. In the cultivar under study, in terms of height, anthers did not reach the apical region of the flower receptacle; consequently, pollen grains did not fertilize stigmas in that region, originating fruits with deformations.

Nannotrigona testaceicornis pollination increased the pollination value by $22.6 \%$, expressed in fresh fruit weight due to the movements of this bee species in the flower, by the pollen distribution in stigmas of the basal, lateral and apical regions the flower receptacle. In addition, with the addition of other pollinating agents through natural pollination, the pollination value increased by $11.3 \%$ the fresh fruit weight.

Similar results for the contribution in fresh fruit weight were verified by WITTER et al. (2012), when studying self-pollination and entomophilous pollination with Plebeia nigriceps bee species in the strawberry cultivar Aromas.

The results verified in this study indicate that self-pollination alone is not capable of promoting all the productive potential of the cultivar San Andreas and, for this reason, there was pollination deficit. Nannotrigona testaceicornis visits implied in considerable increases in the average fresh fruit weight, which contributed to the productive potential of the cultivar. However, natural pollination, comprised by the combination of self-pollination, wind pollination, $N$. testaceicornis pollination and other pollinating insects, expressed the maximum pollination potential in fresh fruit weight. However, it is emphasized that, probably, the increase in the number of $N$. testaceicornis visits may contribute more significantly to the fresh fruit weight in relation to the results obtained.

\section{CONCLUSIONS}

Natural and $N$. testaceicornis pollination services provided improvements in the quality and added value of fruits, regarding the absence of deformations and marketability, with $N$. testaceicornis being an effective strawberry pollinator. 
ACKNOWLED GEMENTS: Not aplicable.

FUNDING: This study was financed in part by the Coordenação de Aperfeiçoamento de Pessoal de Nível Superior Brazil- Finance Code 001.

CONFLICTS OF INTEREST: All authors declare that they have no conflict of interest.

ETHICAL APPROVAL: Not applicable.

AVAILABILITY OF DATA AND MATERIAL: The datasets generated and/or analyzed during the current study are available from the corresponding author on reasonable request.

AUTHORS' CONTRIBUTIONS: Conceptualization: Silva, G.R.; Pérez-Maluf, R. Data Curation: Silva, G.R.; Pérez-Maluf, R. Formal Analysis: Silva, G.R.; Pérez-Maluf, R.; Ribeiro, G.S. Investigation: Silva, G.R.; Pérez-Maluf, R.; Gusmão, A.L.J. Methodology: Silva, G.R.; Pérez-Maluf, R.; Ribeiro, G.S; Gusmão, A.L.J. Writing - Review \& Editing: Silva, G.R.

| | | | | | | | | | | | | | | | | | | | | | | | | | | | | | | | | | | | | | | | | | | | | | | | | | | | | | | | | | | | | | | | | | | | | | | | | | | | | | | | | | | | | | | | | | | | | | | | | | | | | | | | | | | | | | | | | | | | | | | | | | | | | | | | | | | | | | | | | | | | | | | | | | | | | | | | | | | | | | | | | | | | | | | | | | | | | | | | | | | | | | | | | | | | | | | | | | | | | | | | | | | | | | | | | | | | | REFERENCES

ABROL, D.P.; GORKA, A.K.; ANSARI, M.J.; AL-GHAMDI, A.; AL-KAHTANI, S. Impact of insect pollinators on yield and fruit quality of strawberry. Saudi Journal of Biological Sciences, Riyadh, v.26, n.3, p.524-530, 2019. https://doi.org/10.1016/j.sjbs.2017.08.003

ADHIKARI, R.D.; MIYANAGA, R. Utilization of Hairy Footed Flower Bee Anthophora plumipes (Hymenoptera: Apidae) for Pollination of Greenhouse Strawberry. Advances in Entomology, Greece, v.4, n. 1, p.25-31, 2016. https://doi.org/10.4236/ae.2016.41004

ANTUNES, O.T.; CALVETE, E.O.; ROCHA, H.C.; NIENOW, A.A.; CECCHETTI, D.; RIVA, E.; MARAN, R.E. Produção de cultivares de morangueiro polinizadas pela abelha jataí em ambiente protegido. Horticultura Brasileira, Brasília, v.25, n. 1, p.94-99, 2007. https:// doi.org/10.1590/SO102-05362007000100018

ARIZA, M.T.; SORIA, C.; MEDINA, J.J.; MARTÍNEZ-FERRI, E. Fruitmisshapen in strawberry cultivars (Fragaria $\times$ ananassa) is related to achenes functionality. Annals of Applied Biology, Newport, v. 158, n. 1, p. 130-138, 2011 . https://doi.org/10.1111/j.1744-7348.2010.00451.x

BARTOMEUS, I.; POTTS, S.G.; STEFFAN-DEWENTER, I.; VAISSIÈRE, B.E.; WOYCIECHOWSKI, M.; KREWENKA, K.M.; TSCHEULIN, T.; ROBERTS, S.P.M.; SZENTGYÖRGYI, H.; WESTPHAL, C.; BOMMARCO, R. Contribution of insect pollinators to crop yield and quality varies with agricultural intensification. PeerJ, London, v.2, p.e328, 2014. https://doi.org/10.7717/peerj.328

BLÜTHGEN, N.; KLEIN, A.-M. Functional complementarity and specialisation: The role of biodiversity in plant-pollinator interactions. Basic and Applied Ecology, Göttingen, v.12, n.4, p.282-291,2011.https://doi.org/10.1016/j.baae.2010.11.001

CSUKASI, F.; OSÓRIO, S.; GUTIERREZ, J.R.; KITAMURA, J.; GIAVALISCO, P.; NAKAJIMA, M.; FERNIE, A.R.; RATHJEN, J.P.; BOTELLA, M.A.; VALPUESTA, V.; MEDINA-ESCOBAR, N. Gibberellin biosynthesis and signalling during development of the strawberry receptacle. New Phytologist, Lancaster, v.191, n.2, p.376-390, 2011 . https://doi.org/10.1111/j.1469-8137.2011.03700.x
SANTOS, H.G.; JACOMINE, P.K.T.; ANJOS, L.H.C.; OLIVEIRA, V.A.; OLIVEIRA, J.B.; COELHO, M.R.; LUMBRERAS, J.F.; CUNHA, T.J.F. (ed.). Sistema Brasileiro de Classificação de Solos. Rio de Janeiro: Embrapa Solos, 2006. 306p. Available from: https://www. infoteca.cnptia.embrapa.br/infoteca/bitstream/doc/338818/1/ sistemabrasileirodeclassificacaodossolos2006.pdf. Access on: 4 Ago. 2017.

GHOSH, S.; JUNG, C. Global Honeybee Colony Trend is Positively Related to Crop Yields of Medium Pollination Dependence. Journal of apiculture, Korea, v.31, n.1, p.85-95, 2016. https://doi. org/10.17519/apiculture.2016.04.31.1.85

GIANNINI, T.C.; CORDEIRO, G.D.; FREITAS, B.M.; SARAIVA, A.M.; IMPERATRIZ-FONSECA, V.L. The Dependence of Crops for Pollinators and the Economic Value of Pollination in Brazil. Journal of Economic Entomology, Texas, v.108, n.3, p.849-857, 2015. https://doi.org/10.1093/jee/tov093

KLATT, B.K.; HOLZSCHUH, A.; WESTPHAL, C.; CLOUGH, Y.; SMIT, I.; PAWELZIK, E.; TSCHARNTKE, T. Bee pollination improves crop quality, shelf life and commercial value. Proceedings of the Royal Society B, Toronto, v.281, n. 1775, p.20132440, 2014. https:// doi.org/10.1098/rspb.2013.2440

MALAGODI-BRAGA, K.S. Estudo de agentes polinizadores em cultura de morango (Fragaria $\times$ ananassa Duchesne - Rosaceae). 2002. Thesis (Doctorate of Science in Ecology) - Universidade de São Paulo, São Paulo, 2002. Available from: https://www.teses.usp. br/teses/disponiveis/41/41 134/tde-27092004-164949/ pt-br.php. Access on: 10 Jun. 2017.

MALAGODI-BRAGA, K.S.; KLEINERT, A.M.P. Como o comportamento das abelhas na flor do morangueiro (Fragaria ananassa Duchesne) influencia a formação dos frutos? Bioscience Journal, Uberlândia, v.23, Suppl.1, p.76-81, 2007. Special Issue. Available from: http://www.seer.ufu. br/index.php/biosciencejournal/article/view/6831. Access on: 10 Jun. 2017. 
PROGRAMA BRASILEIRO PARA A MODERNIZAÇÃO DA HORTICULTURA \& PRODUÇÃO INTEGRADA DE MORANGO (PBMH \& PIMo). Normas de classificação de morango. São Paulo: CEAGESP, 2009. (Documentos, 33). Available from: http://www. ceagesp.gov.br/wp-content/uploads/2015/07/morango.pdf. Access on: 5 Ago. 2020.

R CORE TEAM. R: A language and environment for statistical computing. Vienna: R Foundation for Statistical Computing, 2017. Available from: http://www.R-project.org. Access on: 20 jun. 2017.

ROSELINO, A.C.; SANTOS, S.B.; HRNCIR, M.; BEGO, L.R. Differences between the quality of strawberries (Fragaria $\mathrm{x}$ ananassa) pollinated by the stingless bees Scaptotrigona aff. depilis and Nannotrigona testaceicornis. Genetics and Molecular Research, Ribeirão Preto, v.8, n.2, p.539-545, 2009. https://doi.org/10.4238/vol8-2kerrO05

SANDHU, H.; WATERHOUSE, B.; BOYER, S.; WRATTEN, S. Scarcity of ecosystem services: an experimental manipulation of declining pollination rates and its economic consequences for agriculture. PeerJ, London, v.4 e2099, 2016. https://doi.org/10.7717/peerj.2099

SHARMA, H.K.; GUPTA, J.K.; RANA, B.S.; RANA, K. Insect pollination and relative value of honey bee pollination in strawberry, Fragaria ananassa Duch. International Journal of Farm Sciences, Solan, v.4, n.2, p.177-184, 2014. Available from: http://www.indianjournals. com/ijor.aspx?target=ijor:ijfs\&volume $=4 \&$ issue $=2 \&$ article $=026$. Access on: 4 Ago. 2020.
SILVEIRA, F.A.; MELO, G.A.R.; ALMEIDA, E.A.B. Abelhas brasileiras: sistemática e identificação. Belo Horizonte: Fernando A. Silveira, 2002, 253p.

TUOHIMETSÄ, S.; HIETARANTA, T.; UOSUKAINEN, M.; KUKKONEN, S.; KARHU, S. Fruit development in artificially self- and crosspollinated strawberries (Fragaria $\times$ ananassa) and raspberries (Rubus idaeus). Acta Agriculturae Scandinavica, Section B - Soil (2) Plant Science, Uppsala, v.64, n.5, p.408-415, 2014. https:// doi.org/10.1080/09064710.2014.919348

WITTER, S.; RADIN, B.; LISBOA, B.B.; TEIXEIRA, J.S.G.; BLOCHTEIN, B.; IMPERATRIZ-FONSECA, V.L. Desempenho de cultivares de morango submetidas a diferentes tipos de polinização em cultivo protegido. Pesquisa Agropecuária Brasileira, Brasília, v.47, n.1, p.58-65, 2012. https://doi.org/10.1590/ So $100-204 \times 2012000100009$

ZAPATA, I.I.; VILLALOBOS, C.M.B.; ARAIZA, M.D.S.; SOLÍS, E.S.; JAIME, O.A.M.; JONES, R.W. Effect of pollination of strawberry by Apis mellifera $\mathrm{L}$. and Chrysoperla carnea $\mathrm{S}$. on quality of the fruits. Nova Scientia, Mexico, v.7, n.13, p.85-100, 2014. https://doi. org/10.21640/ns.v7i13.12

ŻEBROWSKA, J. Influence of pollination modes on yield components in strawberry (Fragaria $\times$ ananassa Duch.). Plant Breeding, Bonn, v.117, n.3, p.255-260, 1998. https://doi. org/10.1111/j.1439-0523.1998.tb01935.x 